\title{
An Overview on Narcotic Drugs and Psychotropic Substances Act, 1985
}

\author{
Shweta Sharma*, Kapil Kumar ${ }^{2}$ and Gyanendra Singh ${ }^{3}$ \\ ${ }^{1}$ Raksha Shakti University, India \\ ${ }^{2}$ Department of Forensic Science, Gujarat University, India \\ ${ }^{3}$ National Institute of Occupational Health, India
}

Submission: August 19, 2017; Published: August 24, 2017

*Corresponding author: Shweta Sharma, Ph D Research Scholar, Raksha Shakti University, Meghaninagar, Ahmedabad, India, Email: shwetadec1@gmail.com

\begin{abstract}
Narcotic Drugs and Psychotropic Substances Act also commonly termed as the NDPS Act, made with the purpose to control drugs of abuse and prohibit its use, dissipation, distribution, manufacture, and trade of substance of abuse. Narcotic drugs are those which induce sleep while psychotropic substances have the ability to alter the mind of an individual. NDPS Act came into existence on 14 November 1985 by Parliament of India. Although, as these kinds of drugs have their importance in the practice of medicine. Thus, the act also has provisions for the cultivation of cannabis, poppy, or coca plants and manufacture of any psychotropic substances dealing with the medicinal practices. Main agenda of the act is to have a control on manufacture, possession, sale and transport of such narcotic and psychotropic substances. The act bans around 200 psychotropic substances resultant upon these drugs are not available over the counter for any walk in individual. These drugs are on sale only when prescription for the same is available. Violation of this law may result into punishment including rigorous imprisonment or fine or both. The degree of punishment is dependent upon the harshness of the case being dealt with. If the drugs are used for personal use then the punishment may be lesser. Although since the establishment of the law, it has been amended time and again. But due to the availability of synthetic drugs and issues relating to street drugs and designer drugs, the problem in dealing with new drugs having the nature of substance of abuse is a difficult task. Besides NDPS also lacks in differentiating among users, drug peddler and hard core criminals in this drug trade. The present study is an overview on the NDPS act and its competency.
\end{abstract}

Keywords: Narcotics; Psychotropic substance; NDPS; Prohibition

\section{Introduction}

India also known as the land of Shiva, has inherited cultural routes with most mysterious and eccentric ways of worshiping lords. One of these is using bhang a form of cannabis for celebrating religious festival named as Shivaratri. "Soma" is a Sanskrit word which also means intoxicating, a property induced by narcotic drugs, which have been used as "soma ras" since centuries described in many literatures too. Apart from cannabis, opium is also offered at akha teej, a ceremony, which is celebrated to strengthen family bonding [1]. Unlike western countries India has a cultural connection of adapting certain natural forms of narcotic substances for celebrating some religious festivals. Thus, this cultural difference is an important aspect to be considered while framing and forcing any drugs laws in India.
On the other hand we cannot overlook the menace of substance of abuse, which is on a rise in our country. We have a large number of drug addicts in the society. Substance abuse brings a lot of problems related to, health like mortality, and psychiatric disorders as well as economic issues like finances spent on developing services, drain on national resources, loss of productivity. It also leads to a number of social problems which can be defined under family disintegration that can also lead to criminal activities [2,3]. The war on drugs has resulted in more sensitive issues than in any other phenomenon in our history. It may be the cause of crimes ranging from white collar crimes to blue collar crimes. In the era of terrorism where drugs are a way of producing funds for terrorist activities it is a very important area which should be taken into consideration while framing and amending laws related to drugs. 
Effective laws are a necessity to fight the nuisance associated with drugs. In a period of less than a year around 14, 564 people got arrested under the NDPS Act in Punjab with almost one third prisoners were arrested in criminal cases related to drugs. To compensate with the situation government came up with special drives aiming at discouraging drug abuse [4]. India is one of the members of three United Nations drug conventions -1961 Single Convention on Narcotic Drugs, 1971 Convention on Psychotropic Substances and 1988 Convention against Illicit Traffic in Narcotic Drugs and Psychotropic [1]. These treaties came in effect in 1980s after a lot of debate on abolishing nonmedical use of opium and cannabis.

\section{Drug Policy in India}

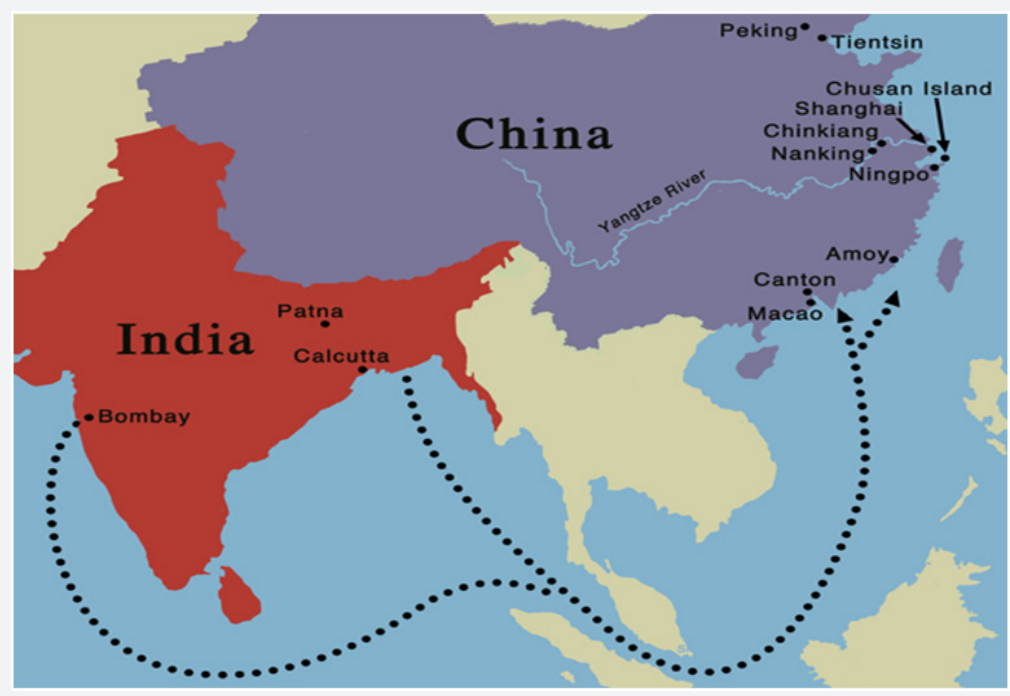

Figure 1: Map depicting route of opium trade from India to China in 1910.

Among the developing countries India was one of the first countries which devised National Drug Policy (NDP) to make drugs available to poor ones despite the leading brands of pharmaceuticals taking over through the prescription by medical practitioners. In 1963 Indian government passed a drug price control order (DPCO) to keep a check on the prices of drug in market. While DPCO did not bring much difference, since, many drug manufacturers withdrew from the country. Production of certain drugs shifted to China from India. The reformed DPCO came into existence in 2013. DPCO 2013 was found to be more favorable towards non-controlled products as no new investments were carried out. Drugs included in National List of Essential Medicines (NLEM) were only being regulated as per the provisions of DPCO 2013 [5,6] (Figure 1).

During the British rule Chinese became successful in breaking off the India-China opium trade with the help of Britishers. After various international conventions banning substance of abuse all over the world, India adopted NDPS in 1985. Although after 3 years of implementation of NDPS act the need to bring one more act on prevention of illicit trafficking in narcotic drugs and psychotropic substances, 1988 was felt and it was brought under the light of Indian law makers [7].

\section{Enactment of NDPS}

Initially main cause of narcotic addiction was use of opium and morphine for medical preparation during civil war. During these wars veterans became addicted to these drugs and thus, it was also termed as soldier's disease [8]. Although production of hemp (marijuana) had been effectively banned in 1937, while during World War II, some governments all of a sudden discovered they needed it for basics such as rope and other cordage purposes [9]. As far as Indian scenario is concerned use of cannabis documented dates back to vedic period. Atharvaveda documents the cannabis used for which was a few hundred years ago [10]. In India until 1985 Cannabis and its derivatives (bhang, charas and ganja) were legally sold and were commonly used for recreational purposes.

India opposed the Single Convention on Narcotic Drugs (1961) which was proposed by United States under law against all drugs. Thus the convention came to a favorable decision giving India a "Grace period" of 25 years to make cannabis available for scientific and medical purpose and not for any other reason. Since it was a politically sensitive issue and India became obligated to the international delegations. This compelled Indian government to eliminate ethnically deep-seated use of cannabis. Consequently on 14 November 1985, NDPS Act was enacted, banning all narcotic drugs in India without much resistance. The only provision for non-medical cultural use within the $1985 \mathrm{Act}$ was that drinks made from cannabis leaves were to be sanctioned Britto 1989. NDPS Act mainly prohibits cultivation, manufacture, possession, sale, transport etc, of these drugs and substances 
except for medical and scientific purposes as provided in the act [11]. Drugs covered under this act include cannabis, coca, opium or any other narcotic substance. Main aims for enforcing this law were to control the manufacturing and distribution of drugs, to keep a check on quality of drugs, to mandate display of ingredients of drugs and to prevent substance abuse in society.

\section{Major shortcomings of the law}

Table 1: Common drugs in NDPS Act.

\begin{tabular}{|c|c|c|c|c|c|}
\hline Drugs & SmallQuantity & Punishment & $\begin{array}{c}\text { Commercial } \\
\text { Quantity }\end{array}$ & Punishment & $\begin{array}{c}\text { Intermediate(In between } \\
\text { smaller \& commercial } \\
\text { quantity) }\end{array}$ \\
\hline Heroin & $5 g$ & \multirow{9}{*}{$\begin{array}{c}\text { Maximum of } 1 \\
\text { year rigorous } \\
\text { imprisonment or a } \\
\text { fine up to Rs } 10,000 \\
\text { or Both. }\end{array}$} & $250 \mathrm{~g}$ & \multirow{9}{*}{$\begin{array}{l}\text { Rigorous } \\
\text { imprisonment from } \\
10 \text { years (min) to } 20 \\
\text { years (max) and a } \\
\text { fine from Rs } 1 \text { lakh to } \\
2 \text { lakhs. }\end{array}$} & \multirow{9}{*}{$\begin{array}{l}\text { Rigorous imprisonment that } \\
\text { may extend to } 10 \text { years \& fine } \\
\text { that may extend to Rs } 1 \text { lakh. }\end{array}$} \\
\hline Opium & $25 \mathrm{~g}$ & & $2.5 \mathrm{~kg}$ & & \\
\hline Morphine & $5 \mathrm{~g}$ & & $250 \mathrm{~g}$ & & \\
\hline Ganja (cannabis) & $1 \mathrm{~kg}$ & & $20 \mathrm{~kg}$ & & \\
\hline $\begin{array}{c}\text { Charas(cannabis } \\
\text { resin) }\end{array}$ & $100 \mathrm{~g}$ & & $1 \mathrm{~kg}$ & & \\
\hline Coca leaf & $100 \mathrm{~g}$ & & $2 \mathrm{~kg}$ & & \\
\hline Cocaine & $2 \mathrm{~g}$ & & $100 \mathrm{~g}$ & & \\
\hline Amphet-Amine & $2 \mathrm{~g}$ & & $50 \mathrm{~g}$ & & \\
\hline LSD & $2 \mathrm{mg}$ & & $100 \mathrm{mg}$ & & \\
\hline
\end{tabular}

One of the major drawbacks of the act is that it presumes the guilt of the accused which brings complete responsibility of proving an individual's innocence on him. Bails cannot be given to accused of offences which fall under Sections 19, 24 or 27A of the NDPS Act and those relating to commercial quantities of drugs [12]. Common drugs in NDPS Act [13], (Table 1). Although Indian judicial system considers each person innocent till proven otherwise. "Justice Delayed is Justice Denied" in spite of availability of special courts assigned for specific cases under this act delayed judgments are too common. Certain times accused arrested for having small quantity of drugs are freed after long time in custody during the investigation period. One of the most important reasons for slackness of such drug laws is investigators are much concentrated on big players who are selling drugs on large scale than regular drug peddlers. Besides, corruption that is a parasite to any system has its effect in investigations relating to drugs. Few convictions are seen in drug cases while amount of drugs in street gives a larger figure [14].

There is no difference between hard drugs and soft drugs for example heroine is a harder drug than opium in its natural form. Heroin can be easily delivered illegally since a very small quantity is required for the kick to an addict as compared to natural form of opium. Since somewhere selling heroine generates more profits, drug peddlers prefer it over opium. It is somehow increasing the circulation of synthetic drugs among drug users which have instantly stronger effect on the biological system. In section 54 of NDPS act it is stated that unless the contrary is proved it shall be presumed that the accused was had committed an offence related to drugs. Harsher punishment has been forced for repeated offences. According to an amendment in 1989, in section $31 \mathrm{~A}$ mentions death penalty for repeated offences if the quantity of drug seized is more than the certain limits. Many times it is debated that the NDPS Act does not distinctively differentiates between a casual drug user, a hard addict, a petty peddler and a seasoned drug trafficker. Apart from the sections defined which might need some reforms it is a necessity that this act should be reviewed time to time, since, every now and then a new drug or its derivative comes in existence as an addictive substance. For example, a new type of substance with basic similarities with amphetamine was seized in quite a large quantity in Maharashtra, India, about 2,640 bottles of Rescox cough syrup valuing for Rs.3lakh were seized [15].

In such new kind of drugs and derivatives it becomes difficult to justify it under NDPS Act. Inclusion of new precursors, drugs and their derivatives with narcotic and psychotropic effect in act is required for increasing the effectiveness of the law. A study carried out by a group of researchers also suggests that opioids and alcohol be treated similarly. It reports the age of onset and pattern of dependence same in both alcohol and opioids. Rates of alcohol problems range from drunk driving to heinous crimes too. Therefore certain legislations should be considered for use of alcohol and its dependence leading to social problems [16]. On an average 76 percent were prosecuted and 28 percent were convicted in cases related to drugs according to a study conducted in Tihar jail. Indicating the ratio of conviction being too low against the drug cases reported.

\section{NDPS Amendments, 2014}

NDPS amendment 2014 came in force on 1 May 2014. Under section 71 of NDPS act which explains the management of drug dependents cases and the rules for treatment facilities was incorporated. At the same time, the amendments increased penalties for low-level offences and continued to criminalize the consumption of drugs [17]. Producers of morphine just need 
a single license from respective State Drugs Controller unlike the earlier procedure which had prolonged steps and multiple licenses of different validation period [18]. The amendment will ensure a uniform regulation for the whole country, eliminating state wise conflicts. Essential Narcotic Drugs which are used in medicinal preparations also including; Morphine, Fentanyl and Methadone, have been relaxed for easy accessibility among treatments provided. The death sentence for repeated conviction for trafficking large quantities of drugs has been diluted with giving courts to discretely sentence for 30 years. On the other hand, punishment has been increased for "small quantity" offences from a maximum of 6 months to 1 year imprisonment after this amendment [19].

\section{Considerations for Future}

Effective implementation of NDPS act for regulating the drugs and its usage in the society needs to be kept under view. Ensuring the quality of drugs used for medical purposes is an important aspect which should be taken into consideration. Data of drug addicts should be well maintained and regulated incorporating various organizations working in this area. Improvising co-ordination among states for investigation in cases related to drugs. Differentiating synthetic drugs from natural drugs can be helpful for clear lines of investigation. Transparency of the policy can be a great advent for effectively solving crimes related to drugs. Understanding the drug patterns is an essential requirement for eliminating the problem of illegal drugs from our country. Bringing awareness and educating can help in eradicate the problem of drug addiction in our country. Rehabilitation centers should co-ordinate with the central and state governments for preventing the substance abuse of drugs and its practice in coming generations from the harms of substance abuse.

\section{References}

1. Molly Charles, Dave Bewley-Taylor, Amanda Neidpath (2005) Drug Policy In India: Compounding Harm? Briefing paper ten. The Beckley Foundation Drug Policy Programme.

2. Anil malhotra, Ashwin mohan (2000) National policies to meet the challenge of substance abuse: programmes and implementation.
Indian Journal of Psychiatry 42 (4): 370-377.

3. Times of India, Ahmedabad (2012) High court shows mercy to 73-year-old drug peddler.

4. Rohan Dua (2014) Drug-related crime reported highest in Punjab: National Crime Records Bureau.

5. http://www.jagranjosh.com/articles/upsc-ias-exam-drug-policy-inindia-1460379300-1.

6. http://www.livemint.com/Opinion/7Htu5u7jHr2SaSDEHkbqHO/ The-rationale-of-Indias-drug-policy.html

7. Convention against the Illicit Traffic in Narcotic Drugs and Psychotropic Substances, 1988, United Nations Office on Drugs and Crime (UNODC) (2009).

8. James Grey (2012) Why Our Drug Laws Have Failed: A Judicial Indictment of War on Drugs. Temple University press, USA.

9. The history of the drug laws.

10. Ram Manohar (2004) Smoking and Ayurvedic Medicine in India. In Sander L Gilman, Zhou Xun (Eds.), Smoke: A Global History of Smoking. Reakton Books, London.

11. CKParikh (2017) Parikh's textbook of medical Jurisprudence, Forensic Medicine and Toxicology. ( $\left.6^{\text {th }} e d n\right)$.

12. George, Joshua Babu and Krishnan, Ashwin (2012) Loopholes in the Narcotic Drugs and sychotropic Substances Act, 1985. Social Science Research Network p. 1-9.

13. Tripti Tandon (2015) Drug policy in India.

14. Sesha Kethineni Lois Guyon Ruth Mclennan Fennick (1995) Drug Use in India: Historical Traditions And Current Problems. International Journal of Comparative And Applied Criminal Justice 19(2): 211-221.

15. Eight-fold increase in drug cases this year (2014).

16. Sahoo Saddichha, Narayana Manjunatha, and Christoday Raja Jayant Khess (2010) Why do we Need to Control Alcohol Use Through Legislative Measures? A South East Asia Perspective? Indian J Community Med 35(1): 147-152.

17. http://www.lawyerscollective.org/updates/parliament-passes-ndpsamendment-bill-2014-gains-losses.html\#more-2762s.

18. http://www.thehindu.com/todays-paper/tp-national/passing-ofndps-act-amendment-bill-will-make-morphine-more-accessible/ article5718188.ece.

19. http://palliumindia.org/cms/wp-content/upload s/2014/01/FAQsAmendment-of-NDPS-2014.pdf.

20. Narcotic Drugs and Psychotropic Substances Act, 1985.

\section{Your next submission with Juniper Publishers} will reach you the below assets

Commons Attribution 4.0 License

DOI: $10.19080 /$ JFSCI.2017.04.555644 